\title{
PENDEKATAN HUMANISTIK PEMBELAJARAN PENDIDIKAN AGAMA HINDU ANAK DISABILITAS (TUNADAKSA) SLB NEGERI 1 TABANAN
}

\author{
Oleh: \\ I Wayan Suarda \\ iwynsuarda@gmail.com \\ Universitas Hindu Indonesia \\ Denpasar
}

Proses Review 04 Februari-12 April, Dinyatakan Lolos 13 April

\begin{abstract}
Disability is an inability of the body to perform certain activities as normal people in general due to the condition in terms of physiological, psychological and anatomical structure or function disorders. The disability is better known by the community as disorder. Disability for some people is a serious problem and can hamper their idias and daily activities. Children with disabilities actually have the same rights as normal society in general, including also in obtaining education especially Hindu religious education that guides and opens the horizons of the mind in living life. This study focuses on the humanistic approach to learning Hinduism of children with disabilities in SLB Negeri 1 Tabanan.
\end{abstract}

Keywords: learning, Hindu religious education, disability, quadriplegic

\begin{abstract}
Abstrak
Disabilitas merupakan suatu ketidakmampuan tubuh dalam melakukan suatu aktivitas atau kegiatan tertentu sebagaimana orang normal pada umumnya akibat kondisi ketidakmampuan dalam hal fisiologis, psikologis dan kelainan struktur atau fungsi anatomi. Disabilitas lebih dikenal oleh masyarakat dengan sebutan penyandang cacat. Kecacatan (Disabilitas) bagi sebagian orang merupakan suatu masalah yang berat serta dapat menghambat cita-cita dan aktivitas kesehariannya. Anak disabilitas sesungguhnya memiliki hak yang sama dengan masyarakat normal pada umumnya. Termasuk juga dalam memperoleh pendidikan terlebih pendidikan agama Hindu yang menuntun dan membuka cakrawala pikiran dalam menjalani kehidupan. Studi ini fokus pada pendekatan humanistik pembelajaran agama Hindu anak disabilitas di SLB Negeri 1 Tabanan.
\end{abstract}

Kata Kunci: Pembelajaran, Pendidikan Agama Hindu, Disabilitas Tunadaksa 


\section{PENDAHULUAN}

Guru sebagai agen pembelajar dan pendidikan dipandang sebagai agen perubahan yang membantu manusia menemukan citra diri sebagai manusia beradab. Agama sebagi panduan moralitas, manusia sehingga mampu menjunjung nilai-nilai kemanusiaannya. Sudah menjadi kewajiban guru memiliki kompetensi dibidangnya sesuai tugas pokok dan fungsinya untuk memahami perkembangan peserta didik. Menurut teori humanistik, tujuan belajar adalah untuk memanusiakan manusia. Proses belajar dianggap berhasil jika sipelajar memahami lingkungannya dan dirinya sendiri.

Teori humanistik atau disebut juga dengan nama lain psikologi kemanusiaan adalah suatu pendekatan yang multiphase terhadap pengalaman dan tingkah laku manusia yang memusatkan perhatian pada keunikan dan aktualisasi diri. Bagi sejumlah psikologi humanistik adalah alternatif, sedangkan bagi sejumlah ahli psikologi yang lainnya merupakan pelengkapan bagi tradisional behaviorisme dan psikoanalisis (misiak dan sexton 2005).

Pemahaman tentang humanistik menurut penganut teori humanistik proses belajar harus berhulu dan bermuara pada manusia. Salah satu tujuannya adalah mencerdaskan kehidupan anak bangsa. Teori humanistik dalamprakteknya cenderung mengarahan siswa untuk berfikir induktif, mementingkan pengalaman, serta membutuhkan keterlibatan siswa secara aktif dalam proses pembelajaran.

Aliran humanistik bertolak dari asumsi bahwa anak atau siswa adalah yang pertama dan utama dalam pendidikan. Ia adalah subjek yang menjadi pusat kegiatan pendidikan. Mereka percaya bahwa siswa mempunyai potensi, punya kemampuan, dan kekuatan untuk berkembang. Para pendidik humanis juga berpegang pada konsep Gestalt, bahwa individu atau anak merupakan satu kesatuan yang menyeluruh. Pendidikan diarahkan kepada membina manusia yang utuh bukan saja segi fisik dan intelektual tetapi juga segi sosial dan afektif terhadap emosi, sikap, perasaan, nilai dan perilaku (Ormrod dan Jeanne Ellis.2009). Artikel ini berupaya menjelaskan tentang pendekatan humanistik dalam pembelajaran anak disabilitas di SLB Negeri 1 Tabanan. Sebelumnya akan dibahas terlebih dahulu tentang humanistic itu sendiri.

\section{METODE}

Penelitian ini menggunakan pendekatan penelitian kualitatif. Teknik pengumpulan data yang digunakan yakni observasi, teknik wawancara terstruktur dan studi pustaka. Teknik pengamatan sangat penting dilakukan untuk melihat model pendekatan humanistik yang digunakan untuk pembelajarn anak-anak disabilitas. Selain itu juga melakukan wawancara dengan tenaga pendidik. Penelusuran pustaka juga penting dilakukan khususnya yang berhubungan dengan kajian ini.

\section{PEMBAHASAN}

Pendekatan humanistik sangat penting bagi anak tunadaksa untuk mendapat perhatian dan diperlukan perlakuan serius, karena yang selama ini metoda yang digunakan guru secara umum sudah maksimal tapi masih dipandang sebelah mata. Pengenalan dan penerapan pendekatan humanistik dalam pembelajaran tentunya akan membangkitkan jiwa mereka, sehingga lebih merasa di hargai dan juga diberikan kesempatan untuk berkembang teori ini dipergunakan sehingga munculah pertanyaan mengapa pendekatan humanistik penting di lakukan dalam pembelajaran pendidikan agama Hindu anak disabilitas terutama kepada anak tunadaksa? Kesempatan sangat baik kepada stakeholders khususnya guru SLB untuk mampu menunjukan profesionalismenya, sebab konsep Kihajar Dewan Tara, pendidikan itu dari, oleh, dan untuk dirinya sendiri yang didampingi oleh guru yang profesional, peserta didik dan orang tua wajib mengikuti aturan sekolah termasuk kedisiplinan (Martinis Yamin. 2007)

\section{1) Guru Humanis}

Humanisasi berarti memanusiakan manusia, menghilangkan keterganntungan, kekerasan dan kebencian dari manusia, dengan melawan tiga hal yaitu: dehumanisasi (objektivasi teknologis, ekonomis, budaya atau Negara), agresivitas (agresivitas kolektif, dan 
kriminalitas), Loneliness (privatisasi, individual). Pendekatan humanistik dalam belajar bertolak dari ide "memanusiakan manusia". Karena itu sebelum menguraikan lebih jauh tentang pendekatan humanistik tersebut, maka persoalan yang perlu dijawab adalah apa yang dimaksud dengan "memanusiakan manusia" itu. (Budiryanto.2005)

Manusia itu terdiri dari dua substansi, yaitu: (1) sunstansi jasad/materi, yang bahan dasarnya adalah dari materi yang merupakan bagian dari alam semesta ciptaan Tuhan. Dan dalam pertumbuhan dan perkembangannya tunduk pada kehendakNya dan mengikuti sunnatullah (aturan, ketentuan, hukum alam yang berlaku di alam semesta); (2) substansi immateri/nonjasadi, yaitu penghembusan/ peniupan ruh (ciptaanNya) ke dalam diri manusia, sehingga manusia merupakan benda organik mempunyai berbagai alat potensial dan fitrah. (Abdurahman, Mulyono. 2012) Prinsip memanusiakan manusia berarti memberikan kesempatan kepada peserta didik untuk mengaktualisasikan dan menumbuhkembangkan alat-alat potensial dan potensi-potennsi dasarnya atau disebut fitrah manusia. (Baharuddin. 2009)

Pandangan mereka berkembang sebagai reaksi terhadap pendidikan yang lebih menekankan segi intelektual dengan peran utama dipegang oleh guru. Pendidikan humanistik menekankan peranan siswa. Pendidikan merupakan suatu upaya untuk menciptakan situasi yang permisif, rileks, akrab untuk mengembangkan segala potensi yang dimilikinya. (Sardiman.A.M.2009). Tugas guru adalah menciptakan situasi yang permisif dan mendorong siswa untuk mencari dan mengembangkan pemecahan sendiri. Pendidikan mereka lebih menekankan bagaimana mengajar siswa (mendorong siswa), dan bagaimana merasakan atau bersikap terhadap sesuatu. Tujuan pengajaran adalah memperluas kesadaran diri sendiri dan mengurangi kerenggangan dan keterasingan dari lingkungan. Ada beberapa aliran yang termasuk dalam pendidikan humanistik yaitu pendidikan: konfluen, kritikisme radikal, dan mistikisme moderen. Pendidikan konfluen menekankan keutuhan pribadi, individu harus merespon secara utuh (baik segi pikiran, perasaan, maupun tindakan), terhadap kesatuan yang menyeluruh dari lingkungan. (Zulkanain. 2008)

\section{2) Profesionalisme Guru dalam penerapan pendekatan Humanistik}

Guru sebagai agen dalam pembelajaran menjadi tanggungjawab moral penuh kesadaran yang disandangnya. Kritikisme radikal bersumber dari aliran naturalisme atau romantisme Rouseau. Mereka memandang pendidikan sebagai upaya untuk membantu anak menemukan dan mengembangkan sendiri segala potensi yang dimilikinya. Pendidikan dan pembelajaran merupakan upaya untuk menciptakan situasi yang memungkinkan anak berkembang optimal. Pendidik yang umumnya disebut guru adalah ibarat petani yang berusaha menciptakan tanah yang gembur, air dan udara yang cukup, terhindar dari berbagai hama, untuk tumbuhnya tanaman yang penuh dengan berbagai potensi. Dalam pendidikan tidak ada pemaksaan, yang ada adalah dorongan dan rangsangan untuk berkembang. Mistikisme moderen adalah aliran yang menekankan latihan dan pengembangan kepekaan perasaan, kehalusan budi pekerti, melalui sensitivity training, yoga, meditasi, dan sebagainya. (Harahap, M Racmhita. 2016)

\section{3) Pemahaman tentang Guru dalam Konsep Catur Guru}

Konsep catur guru berperan dalam membina anak jaman sekarang yang multi kepentingan baik Pemerintah ( selaku guru Wisesa), Orangtua ( guru rupaka), Guru pengajar di sekolah (guru pengajian), dan Tuhan/Ida Sanghyang Widhi Washa ( guru Swadiaya) Semua sebutan guru dalam catur guru memiliki peranan yang berbeda akan tetapi tujuannya satu yaitu membentuk anak saputra yang berkarakter. Pemerintah bertugas mengayomi dan memberlakukan kurikulum dan aturannya, guru pengajian melaksanakan kurikulum untuk mewujudkan pendidikan yang berkarakter, cerdas, dan berdaya guna serta memiliki wawasan luas berdaya saing tinggi.

Guru rupaka memberi tuntunan dan dorongan atau motivasi material dan psikologis untuk meyakinkan anaknya sebagai pewaris 
dan generasi penerus yang cerdas, pintar, ulet dan gigih sebagai penerus keluarga dan bangsa. Guru swadiaya yaitu Tuhan Yang Maha Esa merupakan keyakinan utama dan tertinggi memberi anugrahnya sehingga semua cita-cita dan keinginan akan terwujud dengan satu tekad dan keyakinan dikabulkan oleh pencipta yaitu Tuhan Yang Maha Esa. Para pendukung humanistik menyebutkan tujuan pendidikan adalah suatu proses atas diri individu yang dinamis, yang berkaitan dengan pemikiran, integritas dan otonominya. Guru diharapkan dapat membangun hubungan emosional yang baik dengan peserta didiknya, sehingga terbangun konstruksi mental yang kuat untuk perkembangan individu peserta didik itu selanjutnya. Peran guru dalam pendampingan anak disabilitas dengan modal modal kecakapan vokasional dan kompetensi dasar guru maka peran guru yang diharapkan adalah sebagai berikut:

1) Menghormati individu peserta didik

2) Tampil alamiah, otentik, tidak dibuatbuat

3) Mendengar pandangan realitas peserta didik secara komprehensif;

4) Cakap mengendalikan kondisi dalam pembelajaran

5) Ramah, lembut, sopan dan santun tutur bahasanya

6) Menjadi panutan memberi contoh ketauladanan

Dalam pendekatan humanistik, peserta didik diajar untuk membedakan hasil berdasarkan maknanya. Guru dapat menyediakan kegiatan yang memberikan alternatif pengalaman belajar peserta didik. Pendekatan humanistik melihat kegiatan sebagai sebuah manfaat untuk peserta didik di masa depan dan kelas yang baik akan menyediakan berbagai pengalaman untuk membantu peserta didik menyadari potensi mereka dan orang lain, serta dapat mengembangkannya.

\section{4) Panca Dharma Konsep Hindu dalam Pembelajaran}

Relevansi ajaran Hindu dalam dunia pendidikan sesuai konsep Ki Hajar Dewantara dengan Panca Dharma, yang mengandung makna lima (5) kerangka dasar penunjang pendidikan di Indonesia yaitu:

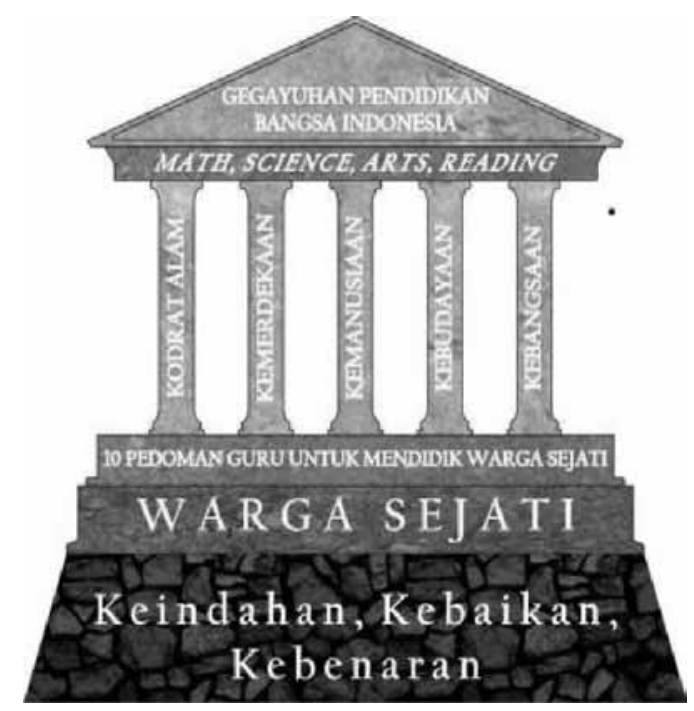

\section{Kodrat Alam}

2. Kemerdekaan

3. Kemanusiaan

4. Kebudayaan

5. Kebangsaan

\section{"Dilandasi oleh keindahan, kebaikan dan kebenaran"}

Pembelajaran humanistik pendidikan agama Hindu yang terkait dengan panca dharma anak disabilitas dapat disimak relevansinya seperti a) Kodrat Alam : siapapun tidak bisa melawan atau menghilangkan kehendak alam karena kodrat, sehingga kita wajib menerimanya dan berusaha meniadakan yang merugikan atau menyulitkan kita. b) Kemerdekaan : setiap insan yang lahir kedunia wajib memperoleh perlindungan, pendidikan dan kesehatan sesuai amanat UUD 1945. c) Kemanusiaan: merupakan hubungan harmonis manusia dengan manusia sesuai (falsapah Tri Hita Karana), Tatwamasi sebagai bentuk kesamaan derajad, sikap toleransi, penyayang, dan harmonis(Titib I Made.1996) d) Kebudayaan: sebagi wujud budaya santun, ramah dan menjunjung tinggi nilai adat istiadat dan budaya daerah maupun Nasional. e) Kebangsaan : merupakan pewarisan sifat nasionalis yang memberi ruang kepada setiap insan untuk selalu menjunjung semangat 
kebangsaan, Nasionalis dan berwawasan luas.

Panca Dharma konsep Hindu ini sangat relevan dengan pendekatan Humanistik dalam pembelajaran pendidikan agama Hindu, guru SLB Negeri 1 Tabanan mampu memadukannya dengan ajaran Kihajar Dewantara sebagai soko guru pendidikan di Indonesia. Prinsip yang perlu dipahami yaitu: Pertama, Ki Hadjar Dewantara membedakan antara pendidikan dengan pengajaran. Pendidikan merupakan upaya kebudayaan yang berazaskan keadaban untuk memberikan dan memajukan tumbuhnya budi pekerti (kekuatan batin, karakter), pikiran (intelek) dan tubuh anak yang selaras dengan dunianya.

Sementara pengajaran adalah pendidikan yang memberikan ilmu pengetahuan dan memberikan keterampilan yang mempengaruhi kecerdasan anak. Kedua, Azas pendidikan Ki Hadjar Dewantara yang menjadi Taman Siswa adalah panca darma (kebangsaan, kebudayaan, kemanusiaan, kemerdekaan, kodrat alam). Panca darma tersebut merupakan kristalisasi dari azas taman siswa 1922 yang kemudian disebut sebagai dasar-dasar 1947.Ketiga, ada dua konsep penting yaitu tri pusat pendidikan dan pendidikan sistem among, masing-masing memiliki kewajiban yaitu: 1) keluarga: mendidik budi pekerti dan perilaku sosial; 2) perguruan: sebagai tempat mencari dan memberikan ilmu pengetahuan, disamping kecerdasan intelektual; 3) pergerakan pemuda: menjadi wilayah merdekanya pemuda untuk melakukan penguasaan diri yang sangat perlu bagi pembentukan watak. Sementara pendidikan sistem among merupakan pemberian kemerdekaan dan kebebasan pada anak atau murid untuk mengembangkan bakatnya sehingga mereka dapat menjadikan hidupnya bermanfaat bagi banyak orang.

\section{PENUTUP}

1. Alasan Pentingnya penerapan pendekan humanistik pembelajaran pendidikan agama Hindu Anak disabilitas tuna daksa adalah a). alasan sosial: alasan sosial merupakan alasan mengembalikan kemampuan peserta didik untuk dapat hidup berdampingan dengan orang lain b). alasan psikologis: merupakan dasar psikologi serta kemampuan anak-anak disabilitas c). alasan empiris: melihat fakta secara langsung terkait keadaan anak disabilitas. d).alasan yuridis: sebagai dasar hukum yang dipergunakan untuk mengembangkan pendekatan humanistiktis pada anak disabilitas.

2. Penerapan pendekatan humanistik dalam pembelajaran mengusahakan partisipasi aktif peserta didik sehingga guru berupaya untuk melibatkan peran aktif peserta didik mengem bangkan kesanggupan belajar atas inisiatif sendiri, berpikir kritis, memaknai proses pembelajaran secara mandiri, bebas mengemukakan pendapat, memilih pilihannya sendiri, melakukan apa yang diinginkan, menerima peserta didik apa adanya, berusaha memahami jalan pikiran peserta didik, memberikan kesempatan untuk maju, dilandasi penerapan pembelajaran Confluent Education, Open Education, Cooperative Learning, Team-Games-Tournament, Student Teams-achievement Divisions, Jigsaw, Group Investigation. 


\section{DAFTAR PUSTAKA}

Abdurrahman, Mulyono. (2012). Pendidikan bagi Anak Berkesulitan Belajar. Jakarta : Rineka Cipta. Baharuddin. (2009). Pendidikan dan Psikologi Perkembangan. Yogyakarta: ArRuzz Media

Budiyanto. (2005). Pengantar Pendidikan Inklusif Berbasis Budaya Lokal. Jakarta: Departemen Pendidikan Nasional, Direktorat Jenderal Pendidikan Tinggi, Direktorat Pembinaan Pendidikan Tenaga Kependidikan dan Ketenagaan Perguruan Tinggi.

Harahap, M Racmhita. 2016. Pendekatan pembelajaran . Jakarta: Rajawali Pers

Martinis Yamin, 2007. Kiat Membelajarkan Siswa. Jakarta. Gaung Persada Press dan Center for Learning Innovation (CLI).

Misiak dan sexton. 2005. Pendidikan dan Psikologi Perkembangan. Yogyakarta: ArRuzz Media

Noverius Laoli. 2007. Elaborasi Pemikiran Ki Hajar Dewantara Tentang Pendidikan. Tersedia [OnLine].http://noveonline.wordpress.com/2007/11/28/8/, 21 Nopember 2019.

Ormrod, Jeanne Ellis. 2009. Psikologi Pendidikan Membantu Siswa Tumbuh dan Berkembang. Jilid 1. Jakarta : Erlangga.

Sardiman. A.M. 2009. Interaksi dan Motivasi Belajar Mengajar. Jakarta: PT. Rajawali Pers

Titib I made.1996. Veda Sabda Suci Pedoman Praktis Kehidupan, Paramita: Surabaya

Totok Amin Soefijanto. 2007. Merekonstruksi Pemikiran Ki Hajar Dewantara. Tersedia

[OnLine]. http://www2.kompas.com/kompas-cetak/0305/26/opini/329113.htm. 21 Nopember 2019.

Zulkarnain. 2008. Transformasi Nilai-nilai Pendidikan . Yogyakarta: Pustaka Pelajar 